\title{
Novel metal-binding hydrogel particles alleviate soil toxicity and facilitate healthy plant establishment of the native metallophyte grass Astrebla lappacea in mine waste rock and tailings
}

M. Bigot School of Agriculture and Food Sciences, The University of Queensland, Australia

J. Guterres School of Agriculture and Food Sciences, The University of Queensland, Australia

L. Rossato School of Agriculture and Food Sciences, The University of Queensland, Australia

A. Pudmenzky School of Agriculture and Food Sciences, The University of Queensland, Australia

D. Doley School of Agriculture and Food Sciences, The University of Queensland, Australia

M. Whittaker Centre for Advanced Macromolecular Design, The University of New South Wales, Australia

U. Pillai-McGarry Sustainable Minerals Institute, The University of Queensland, Australia

S. Schmidt School of Agriculture and Food Sciences, The University of Queensland, Australia

\begin{abstract}
Soil contaminants are potentially a major threat to human and ecosystem health and sustainable production of food and energy where mineral processing wastes are discharged into the environment. It is rarely possible to totally stabilise, render harmless or remove toxic metals from these wastes. Metallophytes (metal-tolerant plants) have evolved mechanisms to survive on many natural metal-rich soils and mining wastes. However, in extreme conditions, metal concentrations in soils/wastes often exceed even the metaltolerance thresholds of metallophytes and the sites remain barren with high risks of contaminant leaching and dispersion into the environment via erosion. A novel soil amendment based on micron-size thiol functional cross-linked acrylamide polymer hydrogel particles (X3) binds toxic soluble metals irreversibly and significantly reduces their concentrations in the soil solution to below the phytotoxicity thresholds. X3 thoroughly mixed with the surface soil layer (top $50 \mathrm{~mm}$ ) of toxic mine waste materials in pots in glasshouse conditions successfully reduced total soluble concentrations of major contaminants in waste rock (aluminium (Al), copper ( $\mathrm{Cu}$ ), zinc ( $\mathrm{Zn})$, cobalt (Co) and manganese (Mn)) and tailings (sodium ( $\mathrm{Na}$ ), sulphur (S), Zn, Mn, Co and cadmium (Cd)) by 90.3 to $98.7 \%$ in waste rock, and 88.6 to $96.4 \%$ in tailings immediately after application. Soil solution $\mathrm{pH}$ was significantly increased from 2.5-3.8 and from 7.1-7.7 in X3-amended waste rock and tailings, respectively. Salinity of the soil solutions (assessed via electrical conductivity (EC)

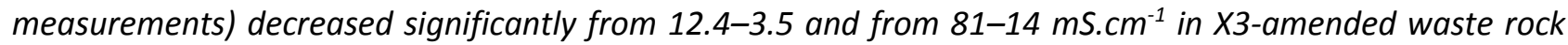
and tailings, respectively. After 61 days, the quality of the unamended bottom layer of the X3-treated pots was also improved and showed significant increase in $\mathrm{pH}$ and reduction of metal concentrations by 91.6 to $95.6 \%$ in waste rock and 64.9 to $84.1 \%$ in tailings, as well as reductions of EC in both mine substrates and reduction of saline element concentrations ( $N a$ and S) by 69 to $74 \%$ in the tailings particularly. Furthermore, the combination of $X 3$ and metallophytes was more efficient at improving soil solution quality than $X 3$ alone. The addition of $X 3$ to the substrates increased substrate water retention and water availability to plants by up to $108 \%$ and $98 \%$ for waste rock and tailings respectively via a substantial reduction in salinity, while it significantly decreased substrate penetration resistance allowing easier root penetration in surface soil. Soil quality improvement by X3 allowed successful early establishment of the native metallophyte grass, Astrebla lappacea, on both waste rock and tailings where plants failed to establish otherwise. In X3amended waste rock, plant establishment percentage (45\%) was not significantly different from the
\end{abstract}


amended sand control (41\%). Although X3-amended tailings had lower establishment percentages (35\%) than the amended sand control (61\%), plants had established at a satisfactory percentage when compared to unamended tailings treatments (0\%). No toxicity or deficiency symptoms were observed on leaves throughout the experiment. The X3 remediation technique promises to be very robust and applicable to a wide range of situations where decades of attempted plant establishment had previously been unsuccessful.

\section{Introduction}

Toxic soil contaminants are a major threat to human and ecosystem health and sustainable food and energy production where up to $25,000 \mathrm{Mt}$ of mineral processing wastes are discharged into the environment worldwide each year (Lottermoser, 2010). Soil acidity also increases the release of metals into the soil and their availability to organisms (Rensing and Maier, 2003). Accumulation of these metals in the food chain can cause severe toxicity to both plants and animals, ultimately leading to highly degraded landscapes with bare soil prone to water and wind erosion, a major issue for global biogeochemical processes and human health and safety (Pimentel, 2006). Fewer than five percent of the 110,000 metalcontaminated sites in Australia have been remediated (CSIRO, 2004). Several established remediation techniques such as excavation and disposal to landfill, creation of physical barriers (i.e. cement, steel, bentonite, grout walls), or chemical amendments (i.e. red mud, zeolite, composts or lime) have been used to help detoxify, revegetate and stabilise landscapes (Mulligan et al., 2001; Garau et al., 2007; Khan and Jones, 2009), thereby enhancing the future safety and environmental sustainability of disturbed areas (LPSDP, 2006). However, these remediation techniques are often very costly, environmentally disruptive and relatively ineffective so areas may be left untreated.

Metallophytes are plant species adapted to grow satisfactorily at extreme plant available soil metal concentrations without showing any sign of toxicity (Baker, 1981). The worldwide occurrence of metallophytes, both in natural and anthropogenic metal-polluted sites (Whiting et al., 2004) is a potential asset for cost-effective plant-based remediation strategies, or phytoremediation (Cunningham and Berti, 1993; Salt et al., 1995), especially phytostabilisation, by which metal-tolerant plants retain metals in the roots (Sinha et al., 2007) or immobilise contaminants through precipitation in the rhizosphere (Sinha et al., 2007; Khan and Jones, 2009). The potential for metallophytes to help rehabilitate highly contaminated lands has been studied extensively (Baker, 1987; Salt et al., 1995; Lasat, 2000; Whiting et al., 2004). Since the late 1980s, phytoremediation has been applied around the world to mine sites experiencing low to medium heavy metal contamination (Wong, 2003) but there has been limited application in Australia due to the few recognised native metallophytes species (Whiting et al., 2004; Pudmenzky et al., 2009). Exotic species are potentially invasive and therefore strictly prohibited for remediation of Australian soils for biosecurity reasons. Moreover, native species may be better adapted to local climatic conditions and low soil nutrient and salinity stresses (LPSDP, 2006; Mendez and Maier, 2008a). The establishment of pioneer metallophyte species is expected to improve soil quality (especially enhance soil water retention and reduce plant available metal content) and facilitate later colonisation by other less tolerant native shrubs and tree species able to stabilise the soil more effectively and extract water from deeper layers (Whiting et al., 2004).

The quality of plant growth media, fundamental for maintaining a healthy environment, is severely affected by two distinct waste streams at mine sites: waste rock that is discarded in the process of accessing the valuable ore, and tailings, which is the residue after extraction of minerals from the ore. Tailings are significantly finer grained (silt or sand size) than waste rock and are considered to be the major source of pollution at mine sites; in addition to containing heavy metals they carry reagents used for mineral extraction and their smaller particle size exposes more of the minerals to oxidative or reductive reactions (Mendez and Maier, 2008b). Soil quality is also often debased by additional high acidity and/or salinity, increasing the availability (and toxicity) of essential elements for plant growth and ecosystem functioning (ASEC, 2001). Unfortunately, high plant available metal concentrations resulting from mining often exceed the threshold for survival of even metallophytes (Wong, 2003; Mendez and Maier, 2008b) and substrate quality needs to be improved first before sowing or planting can be successful (Rossato et al., 2011). 
To this end, Rossato et al. (2011) developed a novel micron-size thiol-functional cross-linked acrylamide polymer as a soil amendment (X3) to facilitate phytoremediation of phytotoxic soils and plant growth media. The base material chosen for the synthesis of $X 3$ is a hydrogel polyacrylamide (PAM), commonly applied in granular form to agricultural lands to improve soil structure, improve water infiltration during irrigation and reduce soil erosion (Levy et al., 1991; Sojka et al., 2007; Hüttermann et al., 2009). Not only can the functional thiols (-SH) attached to the particles bind irreversibly to metals, thereby effectively reducing metal bioavailability to plants in the soil (Rossato et al., 2011), but the high affinity of the hydrogel for water can also increase soil water holding capacity and storage after rainfall and thus provide water for plant uptake during drought (Letey et al., 1992; Rossato et al., 2011). Consequently, X3 can reduce both plant metal toxicity and water deficits, two major issues in Australian degraded lands. This technology, successfully tested under sterile laboratory conditions, showed promising results, especially in the promotion of healthy germination and early root elongation of two native Australian metallophyte grasses (Astrebla lappacea and Austrostipa scabra) under extremely inhospitable mine spoil conditions (high metal concentrations, salinity and low moisture conditions) (Guterres et al., 2012).

This study extended the findings of Rossato et al. (2011) and Guterres et al. (2012) and aimed to assess the effects of X3 metal-binding hydrogel polymer soil amendment alone or in combination with metallophyte grasses, under an extended range of environmental conditions on:

1. The capacity of $X 3$ to ameliorate the poor plant growth media quality and physical characteristics of two contrasting toxic mine waste materials, mine waste rock and tailings.

2. The potential of $X 3$ to promote healthy germination, emergence and early establishment of the native Australian metallophyte grass $A$. lappacea on both contaminated waste rock and tailings in a pot trial.

\section{$2 \quad$ Materials and methods}

\section{$2.1 \quad$ Materials}

\subsubsection{Substrate collection and characterisation}

Two mine spoils, waste rock and tailings, were obtained from Queensland, Australia, sites at which previous attempts at post-mining revegetation had failed. The waste rock was collected from an abandoned gold mine site in late 2009 , to a depth of approximately $10 \mathrm{~cm}$ from the surface. Tailings were collected from a currently operating base metal mine site in February 2011, to a depth of approximately $20 \mathrm{~cm}$ from the surface. The control substrate was river sand, collected in April 2010 from Tamborine Mountain, Queensland, Australia and thoroughly washed with deionised water (DIW). All substrates were air dried, crushed, screened through a $2 \mathrm{~mm}$ sieve, mixed thoroughly in a soil mixer and stored in sealed containers at constant room temperature prior to experiments.

Chemical characteristics of the substrates were obtained by analysis for total metal content, using the hydrofluoric acid decomposition method (Loring and Rantala, 1992) plant available metal content, assessed after extraction with $0.01 \mathrm{M} \mathrm{CaCl}_{2}$ (Menzies et al., 2007) and measured using ICP-MS (Inductively Coupled Plasma Mass Spectrometry) and ICP-OES (Inductively Coupled Plasma Optical Emission Spectroscopy). Soil pH and EC were determined using a digital EC and pH meter in 1:5 soil:water (TPS 901CP, TPS Pty Ltd) after end-to-end shaking for one hour (Rayment and Higginson, 1992).

\subsubsection{Application rate of $X 3$ particles in the substrate mixtures}

Micron-size thiol-functional cross-linked acrylamide particles (X3) that were synthesised as described in Rossato et al. (2011) were mixed thoroughly with the waste rock and tailings substrates in a rotating drum for at least 12 hours. The optimum X3 application rates for each mine substrate were determined based on plant available metal content and salinity levels of the substrates and were $38 \%$ and $19 \%$ of dry weight (DW) of the waste rock and tailings respectively. 


\subsubsection{Native seeds}

Viable seeds of the native metallophyte grass Astrebla lappacea (variety 'Yanda') were obtained from Native Seeds Pty Ltd (Cheltenham, Victoria, Australia). They had been harvested from Walgett (NSW) and stored for over 12 months to overcome dormancy.

\section{$2.2 \quad$ Glasshouse experiment}

A glasshouse experiment was conducted in physical containment level 2 (PC2) temperature controlled conditions set to $30^{\circ} \mathrm{C}$ day and $25^{\circ} \mathrm{C}$ night and with the addition of artificial light on a $12 \mathrm{~h} / 12 \mathrm{~h}$ cycle. Pots (diameter $150 \mathrm{~mm}$ and height $150 \mathrm{~mm}$ ) were lined with sealed plastic bags of $305 \times 205 \mathrm{~mm}$ (BPM Trading Company Pty Ltd) and filled with the substrates to the rim of the pot. Seven treatments were applied in combination with seeds: unamended and X3-amended waste rock ([Waste Rock $+0 \% \times 3$ (plants)] and [Waste Rock $+38 \% \times 3$ (plants)]); unamended and X3-amended tailings [Tailings $+0 \% \times 3$ (plants)] and [Tailings $+19 \%$ X3 (plants)]; and the appropriate controls, unamended sand [Sand $+0 \%$ X3 (plants)]; sand amended with the amount of X3 corresponding to waste rock [Sand $+38 \%$ X3 (plants)]; and sand amended with the amount of X3 corresponding to tailings [Sand $+19 \%$ X3 (plants)]. X3 amendment was applied to the surface (top $50 \mathrm{~mm}$ ) of the pot while the bottom was filled with unamended material. Seeds were first surface sterilised using $20 \%$ bleach as described in Rossato et al. (2011), then sown at a density of 150 seeds per pot. Additional amended tailings [Tailings $+19 \%$ X3 (no plants)] and amended waste rock [Waste Rock $+38 \%$ X3 (no plants)] treatments were set up without plants in order to differentiate the effect of the particles and the metallophyte species on substrate condition. Treatments were replicated three times. Pots were watered daily by weight to maintain moisture levels at field capacity. Nutrient supply was non-limiting to avoid any plant nutrient deficiency that could affect plant growth during the trial and provided through three low strength nutrient solutions ( $A, B$ and $C$ ) specifically designed for Australian native species, each applied every three days. The solutions contained:

- A) $0.0075 \mathrm{~g} \mathrm{~L}^{-1} \mathrm{FeSO}_{4}, 0.03 \mathrm{~g} \mathrm{~L}^{-1} \mathrm{MgSO}_{4}, 0.0625 \mathrm{~g} \mathrm{~L}^{-1} \mathrm{KNO}_{3}, 0.00125 \mathrm{~g} \mathrm{~L}^{-1} \mathrm{CuSO}_{4}, 0.18 \mathrm{~g} \mathrm{~L}^{-1}\left(\mathrm{NH}_{2}\right)_{2} \mathrm{CO}$ (urea).

- B) $0.264 \mathrm{~g} L^{-1} \mathrm{~N}$ (nitrate), $0.0614 \mathrm{~g} L^{-1} \mathrm{~N}$ (ammonium), $0.1351 \mathrm{~g} L^{-1} \mathrm{~N}$ (urea), $0.1474 \mathrm{~g} L^{-1} \mathrm{P}$, $0.7398 \mathrm{~g} \mathrm{~L}^{-1} \mathrm{~K}$ (nitrate), $0.098 \mathrm{~g} \mathrm{~L}^{-1} \mathrm{~K}$ (sulphate), $0.042 \mathrm{~g} \mathrm{~L}^{-1} \mathrm{~S}, 0.0015 \mathrm{~g} \mathrm{~L}^{-1} \mathrm{H}_{3} \mathrm{BO}_{3}, 0.0005 \mathrm{~g} \mathrm{~L}^{-1} \mathrm{Zn}$ (EDTA chelate), $0.0003 \mathrm{~g} \mathrm{~L}^{-1} \mathrm{Mo}, 0.0005 \mathrm{~g} \mathrm{~L}^{-1} \mathrm{Cu}$ (EDTA chelate), $0.0037 \mathrm{~g} \mathrm{~L}^{-1} \mathrm{Fe}$ (DTPA chelate), $1.00 \mathrm{~g} \mathrm{~L}^{-1} \mathrm{Mn}$ (EDTA chelate).

- C) $3.00 \mathrm{~g} \mathrm{~L} L^{-1} \mathrm{Ca}\left(\mathrm{NO}_{3}\right)_{2}$.

\subsubsection{Determination of substrate quality}

\subsubsection{Plant available water and osmotic potential measurement}

Substrate water release characteristics in the presence and absence of $X 3$ particles were assessed to estimate the amount of plant available water held between field capacity $(-0.01 \mathrm{MPa})$ and permanent wilting point (-1.5 MPa) matric water potentials, $\Psi_{\mathrm{m}}$ (Kramer and Boyer, 1995). Three treatments were tested for each of the substrates and included: (i) substrate (waste rock, tailings or sand) only (i.e. no X3 particles added); (ii) substrate + X3 applied at 19\% of substrate DW; and (iii) substrate + X3 applied at 38\% of substrate DW. Each substrate and treatment had three replicates. Additionally, due to the high salinity of the mine substrates, the osmotic potential, $\Psi_{0}$, of the samples was derived by measuring the total water potential, $\Psi_{\mathrm{T}}$, on subsamples of all treatments and replicates following the matric potential measurements. Matric potential was determined using the pressure plate apparatus (Klute, 1986), wherein water-saturated substrate samples were subject to the appropriate air/nitrogen pressure in an enclosed chamber until water drainage from the samples ceased. Samples were removed from the apparatus and a subsample $(\sim 30 \%)$ from each sample rapidly removed and stored in an airtight glass vial for total potential measurement, and the rest of the sample was oven-dried $\left(105^{\circ} \mathrm{C}\right)$ to determine gravimetric water content $\left(W_{c}\right)$. Plant available water was calculated using Equation (1): 


$$
P A W=W_{c} 0.01-W_{c} 1.5
$$

Where:

PAW = plant available water (in \%DW).

$\mathrm{W}_{\mathrm{c} 0.01}=$ percentage water content of the sample dry weight after $0.01 \mathrm{MPa}$ pressure application.

$\mathrm{W}_{\mathrm{c} 1.5}=$ percentage water content of the sample dry weight after $1.5 \mathrm{MPa}$ pressure application.

Total soil water potential for each subsample was measured soon after using a thermocouple psychrometer (SC-10, Decagon Devices, Pullman, Washington, USA) under constant temperature $\left(23^{\circ} \mathrm{C}\right)$ conditions.

Given that the components of $\Psi_{\mathrm{T}}$ (Brady and Weil, 2004) measured under laboratory conditions are:

$$
\Psi_{\mathrm{T}}=\Psi_{\mathrm{m}}+\Psi_{\mathrm{o}}
$$

Osmotic potential was derived from Equation (3):

$$
\Psi_{\mathrm{o}}=\Psi_{\mathrm{T}}-\Psi_{\mathrm{m}}
$$

Where:

$\Psi_{\mathrm{o}}, \Psi_{\mathrm{T}}$ and $\Psi_{\mathrm{m}}$ are expressed in $-\mathrm{MPa}$.

\subsubsection{Redox potential measurement}

Soil redox potential (Eh) was measured immediately before seed sowing and 61 days after sowing to identify possible oxygen limitations associated with the addition of the X3 hydrogel (Bohn, 1971). A platinum electrode and an $\mathrm{Ag} / \mathrm{AgCl}$ reference probe were connected to a voltmeter and inserted into the substrate at $2 \mathrm{~cm}$ depth. Measurements were taken after two minutes of equilibration and adjusted by $+200 \mathrm{mV}$ to convert to Eh (i.e. redox potential obtained when using a standard hydrogen electrode).

\subsubsection{Soil solution sampling and analysis}

The soil solution from both top $50 \mathrm{~mm}$ and the bottom $100 \mathrm{~mm}$ layers of each pot was sampled using Rhizon Soil Moisture Samplers (EVH Engineering Pty Ltd) immediately before sowing (day 0 ) and 61 days after sowing. Up to $10 \mathrm{~mL}$ of soil solution was extracted and $25 \mu \mathrm{L}$ of $70 \%$ concentrated nitric acid was added per $\mathrm{mL}$ of soil solution to maintain metal solubility (Rossato et al., 2011). Samples were stored at $4^{\circ} \mathrm{C}$ until metal analysis using ICP-MS and ICP-OES.

An additional $5 \mathrm{~mL}$ of soil solution was collected 61 days after sowing and analysed immediately for EC and pH using a calibrated digital EC and pH meter (TPS 901-CP, TPS Pty Ltd).

\subsubsection{Substrate penetration resistance}

Substrate penetration resistance was measured 27 days after sowing to test the effect of X3 on the surface strength of extremely saline substrates. Three readings were made using a Geotester pocket penetrometer with a $15 \mathrm{~mm}$ tip (Facchini, Italy) that was inserted into the surface of the substrate in each pot to a depth of $10 \mathrm{~mm}$ and the readings averaged per pot (this constituted one replicate per treatment). As soil penetration resistance is governed by soil water content (Taylor and Brar, 1991) or potential, readings were made 24 hours after the pots were watered to field capacity (-0.01 MPa) water content in an effort to reduce the effects of water potential difference between treatments and expressed in $\mathrm{kPa}$.

\subsubsection{Determination of emergence, plant establishment and shoot heightS}

Seedling emergence per pot was recorded daily for the first 13 days after A. lappacea seeds were sown. Plant establishment, survival and maximum shoot height were monitored weekly from day 13 onwards. Maximum height was determined by averaging the shoot height of the five tallest plants from each pot (from the base of the shoot to the tip of the longest leaf). Plants were also inspected daily for visible symptoms of metal toxicity and/or nutrient deficiencies. 


\subsection{Statistical analysis}

Data were presented as means and standard errors of three replicates, and they were tested for significant differences between treatment means using Student's t-Tests (and a 95\% confidence interval) using Microsoft Excel 2010. Statistical significance was indicated by $p$-values $<0.05$.

\section{$3 \quad$ Results}

\subsection{Substrate characteristics}

Waste rock was very acidic $(\mathrm{pH}=3.10)$ with high plant availabilities of aluminium $(\mathrm{Al})$, copper $(\mathrm{Cu})$, zinc $(\mathrm{Zn})$, manganese $(\mathrm{Mn})$ and cobalt $(\mathrm{Co})$, which were above the phytotoxicty thresholds for these metals (Mulvey and Elliott, 2000). Tailings, on the contrary, had neutral pH (7.03), therefore lower metal plant availabilities, although $\mathrm{Zn}, \mathrm{Mn}, \mathrm{Co}$, and cadmium ( $\mathrm{Cd}$ ) concentrations were elevated and greater than their respective phytotoxicity thresholds (Mulvey and Elliott, 2000). ECs of 2.87 and $5.54 \mathrm{dS} \mathrm{m}^{-1}$ for waste rock and tailings respectively indicate that both substrates were extremely saline (Mulvey and Elliott, 2000; The State of Queensland, 2011). Sand had no metal contamination and was therefore an appropriate control substrate. The results above are shown in Table 1.

Table 1 Chemical characteristics of waste rock, tailings and sand substrates. Plant available metal content $\left(\mathrm{mg} \mathrm{kg}^{-1}\right)$ was assessed via $0.01 \mathrm{M} \mathrm{CaCl}_{2}$ extraction. Data are represented as the mean \pm standard error $(\mathrm{SE})(n=3)$

\begin{tabular}{|c|c|c|c|c|c|c|}
\hline \multirow[b]{3}{*}{ Element } & \multicolumn{2}{|c|}{ Waste Rock } & \multicolumn{2}{|c|}{ Tailings } & \multicolumn{2}{|c|}{ Sand (Control) } \\
\hline & \multirow[b]{2}{*}{ Total } & \multicolumn{4}{|c|}{ Concentration of Key Metal Contaminants $\left(\mathrm{mg} \mathrm{kg}^{-1}\right)$} & \multirow[b]{2}{*}{$\begin{array}{c}\text { Plant } \\
\text { Available }\end{array}$} \\
\hline & & $\begin{array}{c}\text { Plant } \\
\text { Available }\end{array}$ & Total & $\begin{array}{c}\text { Plant } \\
\text { Available }\end{array}$ & Total & \\
\hline Al & $33,395 \pm 983$ & $621.57 \pm 3.71$ & $10,546 \pm 164$ & $1.78 \pm 1.19$ & $15,049 \pm 294$ & $0.00 \pm 0.00$ \\
\hline $\mathrm{Cu}$ & $1,690.2 \pm 27.1$ & $72.31 \pm 0.43$ & $5,001.64 \pm 74.62$ & $1.49 \pm 0.08$ & $0.00 \pm 0.00$ & $0.00 \pm 0.00$ \\
\hline Zn & $309.3 \pm 6.2$ & $10.30 \pm 0.06$ & $6,617.47 \pm 23.8$ & $24.04 \pm 0.32$ & $7.98 \pm 0.73$ & $0.00 \pm 0.00$ \\
\hline Mn & $375.2 \pm 12.4$ & $22.32 \pm 0.10$ & $1,733.0 \pm 6.6$ & $32.73 \pm 0.15$ & $167.4 \pm 1.5$ & $0.18 \pm 0.03$ \\
\hline Co & $11.03 \pm 0.59$ & $0.43 \pm 0.05$ & $372.0 \pm 3.6$ & $3.62 \pm 0.02$ & $2.19 \pm 0.18$ & $0.05 \pm 0.01$ \\
\hline \multirow[t]{3}{*}{ Cd } & $3.67 \pm 0.42$ & $0.00 \pm 0.00$ & $29.06 \pm 1.80$ & $1.32 \pm 0.02$ & $2.27 \pm 0.21$ & $0.00 \pm 0.00$ \\
\hline & \multicolumn{6}{|c|}{ Other Characteristics } \\
\hline & \multicolumn{2}{|c|}{ Waste Rock } & \multicolumn{2}{|c|}{ Tailings } & \multicolumn{2}{|c|}{ Sand (Control) } \\
\hline $\begin{array}{l}\mathrm{EC}_{1: 5} \text { water } \\
\left(\mathrm{mS} \mathrm{cm}^{-1}\right)\end{array}$ & \multicolumn{2}{|c|}{$2.87 \pm 0.03$} & \multicolumn{2}{|c|}{$5.54 \pm 0.02$} & \multicolumn{2}{|c|}{$0.02 \pm 0.00$} \\
\hline $\mathrm{pH}_{1: 5 \text { water }}$ & \multicolumn{2}{|c|}{$3.10 \pm 0.01$} & \multicolumn{2}{|c|}{$7.03 \pm 0.00$} & \multicolumn{2}{|c|}{$6.71 \pm 0.11$} \\
\hline
\end{tabular}

\subsection{Capacity of $\mathrm{X} 3$ to improve substrate quality and penetration resistance}

\subsubsection{Effect of X3 on plant available water and osmotic potential}

Results from the pressure plate apparatus showed that the addition of $X 3$ significantly increased $(p<0.05)$ not only the water holding capacity of all substrates but also the plant available water (PAW) by up to $108 \%$ and $98 \%$ for waste rock and tailings respectively, for the greater $X 3$ concentration ( $38 \% \mathrm{DW})$. A linear trend of increasing PAW with increasing $X 3$ application rates is apparent within the scope of the experiment (Figures $1(A)$ and $1(B)$ ). 
In the case of extremely saline growth media such as waste rock and tailings (Table 1) (The State of Queensland, 2011), osmotic potential can have a considerable effect on total water potential, and consequently PAW, due to the low chemical potential of the water making water uptake difficult. Hence, PAW derived from the measured matric potential (-0.01 MPa and $-1.5 \mathrm{MPa}$ ) water contents (Figure 1(A) and 1(B)) will overestimate this parameter (from Equation (2)) if osmotic potential is less than zero.

A)

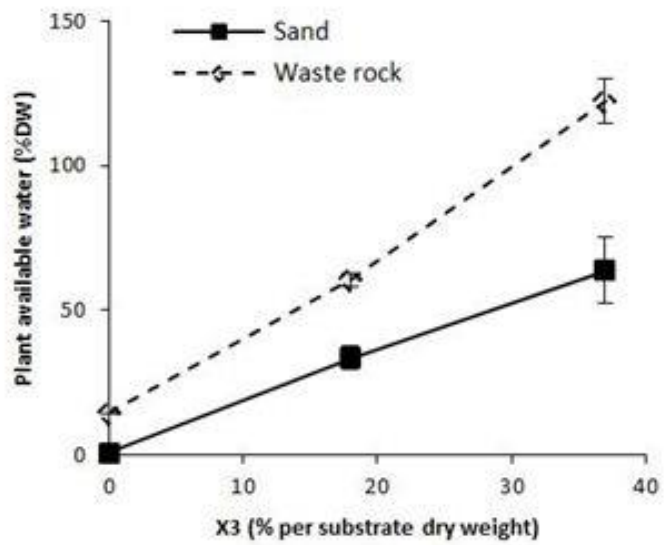

B)

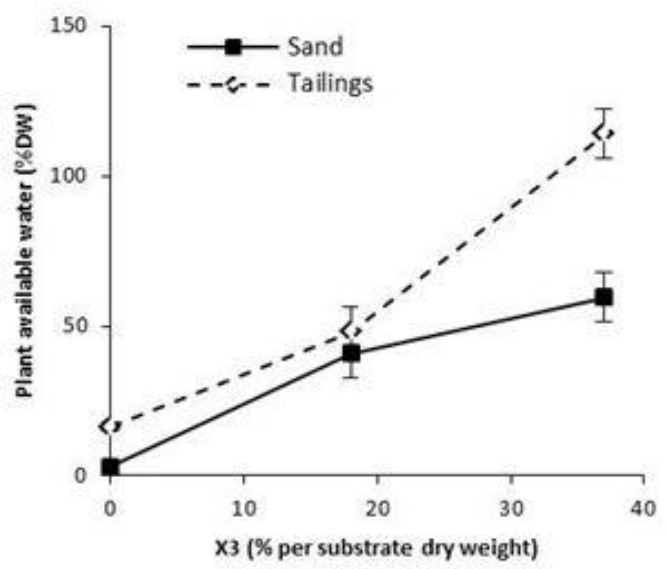

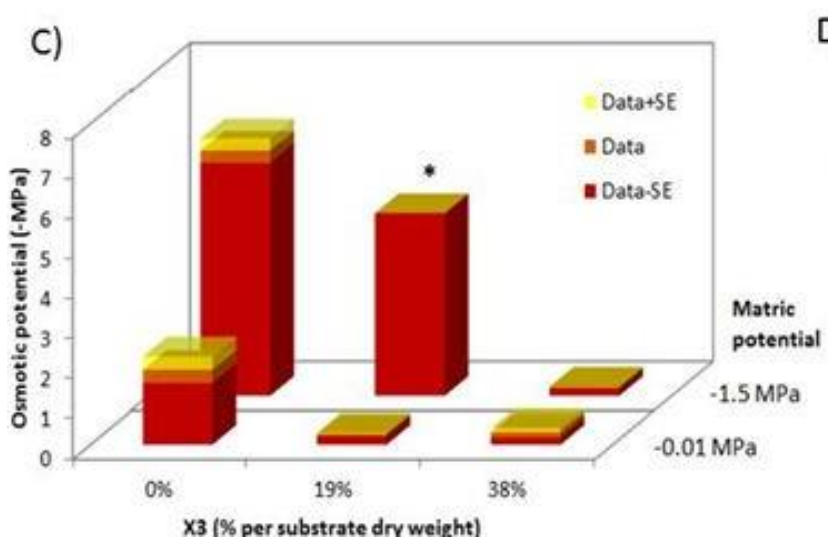

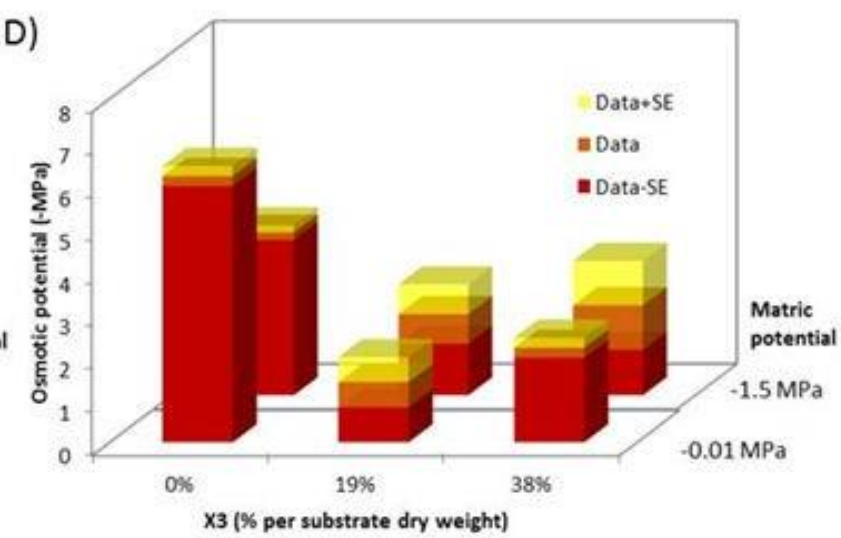

Figure 1 Water characteristics of substrates in the presence of X3: plant available water in waste rock treatments and corresponding sand controls $(A)$ and tailings treatments and corresponding sand controls (B); and osmotic potential of waste rock treatments (C) and tailings treatments (D) at field capacity $(-0.01 \mathrm{MPa})$ and permanent wilting point $(-1.5 \mathrm{MPa})$. Data are represented as the mean \pm standard error $(S E)(n=3)$. Asterisks indicate data based on one replicate only

Figures $1(C)$ and $1(D)$ show that with the addition of $X 3$ particles to the waste rock and tailings, osmotic potential was significantly increased compared to treatments without particles, especially at the larger (38\% DW) concentration of X3 for the waste rock where it was close to zero. This suggests that except for the $38 \% \times 3$ treatment, the PAW obtained for the other waste rock treatments would be overestimates, with the greatest overestimation being for the waste rock only $(0 \% \times 3)$ treatment.

For the tailings (Figure 1(D)), the addition of $X 3$ increased osmotic potential and this was significant at field capacity only $(p<0.05)$. The amount of added X3 had no significant effect $(p<0.05)$ on the osmotic potential at permanent wilting point, although an increasing trend of osmotic potential with the addition of X3 was evident.

\subsubsection{Effect of $X 3$ on substrate redox potential}

On the basis that a biological environment is anaerobic between a redox potential (Eh) of -250 and $+350 \mathrm{mV}$ (Delaune et al., 1990), our study indicated that all waste rock substrates were aerobic with Eh significantly $(p<0.05)$ higher than the $+350 \mathrm{mV}$ threshold (Figure 2(A)). The presence of plants did not 
affect Eh of X3-amended waste rock where it remained constant (approximately $+550 \mathrm{mV}$ ) over time $(p>0.05$, Figure 2(A)). Initial anaerobic conditions were observed in both $\mathrm{X} 3$-amended sand substrates $(+291.8 \pm 1.9 \mathrm{mV}$ [Sand + 38\% X3], Figure 2(A); + $272.9 \pm 3.0 \mathrm{mV}$ [Sand + 19\% X3], Figure 2(B)), and X3amended tailings had Eh just slightly below the limit for aerobic conditions (+ $342.6 \pm 1.2 \mathrm{mV}$ [without plant], $+344.0 \pm 1.0 \mathrm{mV}$ [with plants], Figure 2(B)). While aerobic conditions were restored over time for both sand treatments, X3-amended tailings (+ 307.23 $\pm 12.77 \mathrm{mV}$ [no plants], $+342.6 \pm 11.48 \mathrm{mV}$ [plants], Figure 2(B)) remained slightly below the aerobic threshold for the duration of the trial. However, the tailings treatments with $X 3$ but no plants, showed significantly reduced Eh over time $(p=0.05$, Figure 2(B)), while pots with plants remained unchanged over time $(p>0.05$, Figure $2(B))$.

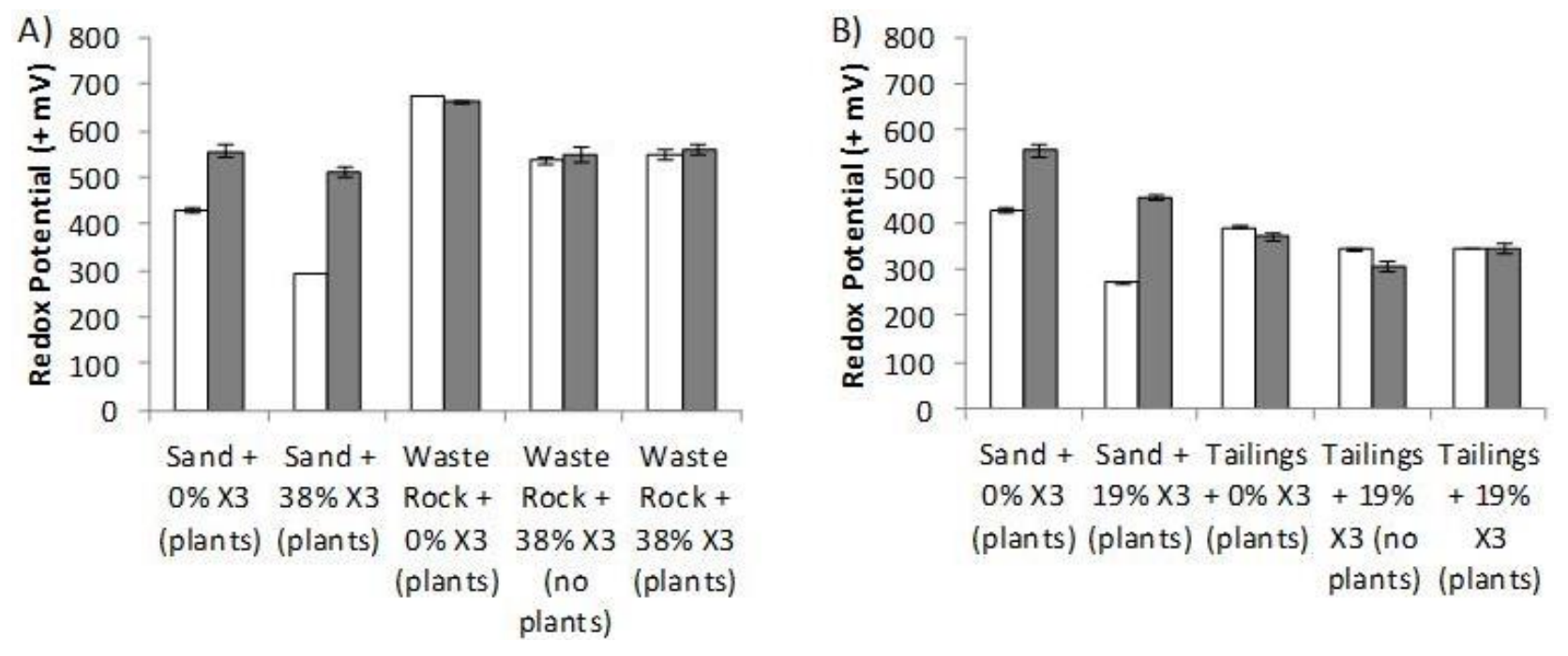

Figure 2 Redox potentials of substrates in pots before sowing (white bars) and 61 days after sowing (dark bars) for waste rock treatments and corresponding controls (A) and tailings treatments and corresponding controls (B). Data are represented as the mean \pm standard error $(\mathrm{SE})(n=3)$

\subsubsection{Effect of $X 3$ on soil solution quality}

With the addition of $X 3$ to the top layer of the pots only and no plants, the substrate solution ECs of both top and bottom layers of the two mine waste materials decreased significantly $(p<0.05)$ after 61 days. The presence of plants on X3-amended pots further reduced EC in both layers of waste rock and tailings $(\mathrm{p}<0.05)$. When $\mathrm{X} 3$ and plants were combined, $\mathrm{pH}$ of both top and bottom layers of waste rock increased significantly $(p<0.05)$ from $2.54 \pm 0.05$ to $3.84 \pm 0.20$ and from $2.33 \pm 0.00$ to $2.86 \pm 0.02$ respectively 61 days after sowing, and this increase of $\mathrm{pH}$ in both layers of waste rock was greater than when $\mathrm{X} 3$ was applied without plants. Similar $\mathrm{pH}$ trends were observed in both layers of tailings $(p<0.05)$ but not in control sand. Results above are shown in Table 2.

Although the chemical compositions of the two waste materials were very different, the addition of X3 drastically reduced the plant availability of all major soluble toxic substrate contaminants, immediately in the top layer and over time in the unamended bottom layer (Tables 3 and 4). In waste rock, addition of X3 instantly reduced $\mathrm{Al}, \mathrm{Cu}, \mathrm{Zn}, \mathrm{Co}$ and $\mathrm{Mn}$ concentrations by $98.7,98.7,94.5,90.3$ and $91.3 \%$ at day 0 (Table 3 ) in the top layer and metal concentrations were maintained below the phytotoxicity threshold for A. lappacea throughout the duration of the experiment. In the bottom layer of the amended waste rock treatment, metal concentrations were gradually decreased by $96.5,94.4,95.4,95.6$ and $91.2 \%$ respectively after 61 days (Table 3). In tailings, similar trends were observed and reductions of $\mathrm{Mn}, \mathrm{Zn}$, Co and $\mathrm{Cd}$ concentrations by $94.7,96.4,92.4$ and $89.7 \%$ respectively occurred immediately in the top layer of the X3amended treatments compared to the unamended tailings (Table 4). The concentrations of these metals in the bottom layer of the amended tailings treatments were reduced gradually by $68,84.1,64.9$ and $82.6 \%$ respectively after 61 days (Table 4). S and Na concentrations also decreased significantly by 88.6 and $89 \%$ respectively in tailings immediately after X3 was applied (from 41,177 $\pm 3,617 \mathrm{mg} \mathrm{L}^{-1}$ and 2,829.8 \pm 
$134.3 \mathrm{mg} \mathrm{L}^{-1}$ in unamended tailings to $4,708 \pm 554 \mathrm{mg} \mathrm{L}^{-1}$ and $307.4 \pm 39.3 \mathrm{mg} \mathrm{L}^{-1}$ in the top layer of the amended tailings, Table 4). Reductions of $\mathrm{S}$ and $\mathrm{Na}$ concentrations in the amended top layer were maintained over time, with no significant difference between solution concentrations at day 0 and day 61 ( $p>0.05$, Table 4). In the bottom layer of the amended tailings, $S$ and Na concentrations were gradually reduced by 74 and $69 \%$ after 61 days compared to unamended pots (Table 4). Overall, in both layers of waste rock and tailings, the combination of $X 3$ and metallophyte grass was more effective at improving soil solution quality than $X 3$ alone $(p<0.05)$ (Tables 3 and 4$)$.

Table 2 Electrical conductivity (EC, $\mathrm{dS} \mathrm{m}^{-1}$ ) and $\mathrm{pH}$ of soil solution from each layer of mine substrates 61 days after sowing. Data are represented as the mean \pm standard error $(\mathrm{SE})(\mathrm{n}=3)$

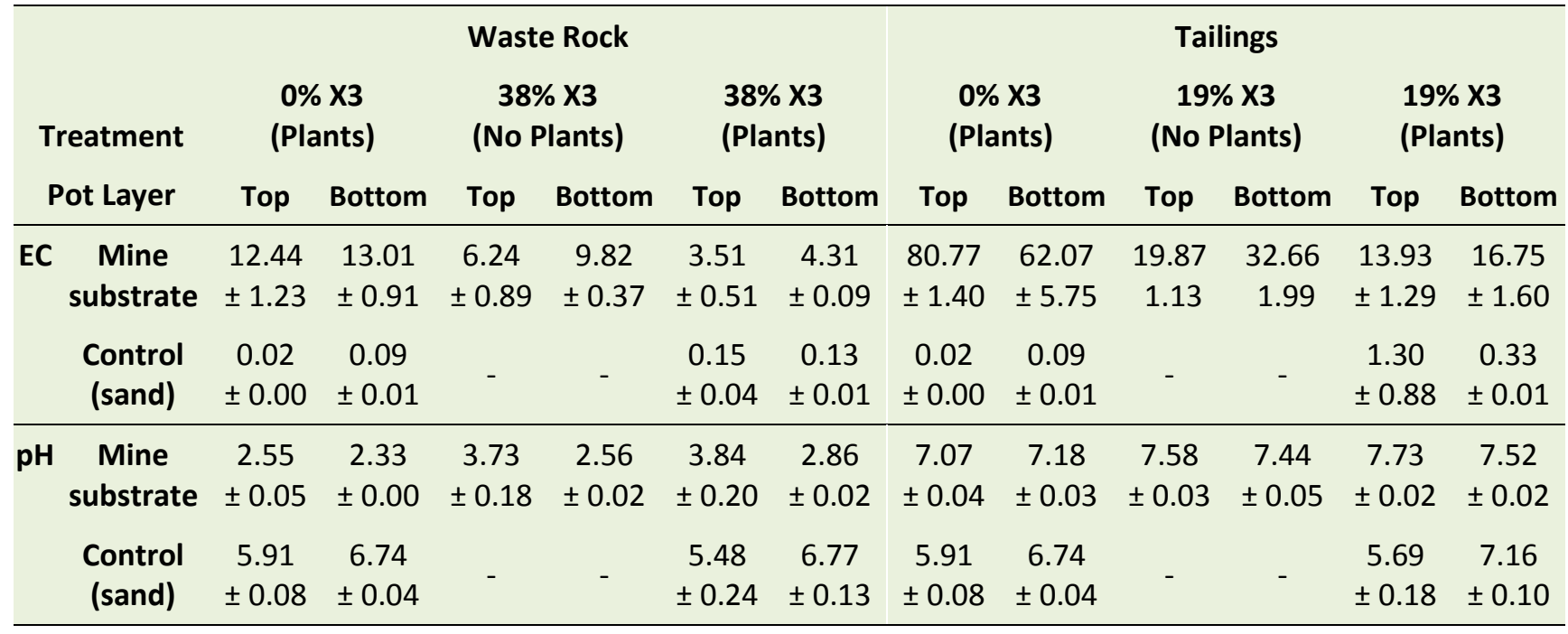

\subsection{Effect of $\mathrm{X} 3$ on substrate penetration resistance}

In the absence of $X 3$, all substrates had significantly greater $(p<0.05)$ surface penetration resistance compared to the treatments with X3 (Figure 3). Values were $200 \pm 11 \mathrm{kPa}$ for unamended sand, $488 \pm$ $42 \mathrm{kPa}$ for unamended waste rock, and $856 \pm 74 \mathrm{kPa}$ for unamended tailings during plant establishment (Figure 3). Apart from the sand, the mine substrate values were large enough to potentially restrict root penetration and exploration (Haling et al., 2011). On the contrary, substrate penetration resistance was substantially $(p<0.05)$ lower in all substrates treated with X3 (Figure 3 ) suggesting that they were no longer detrimental to root penetration (Haling et al., 2011).

\subsection{Effect of $\mathrm{X} 3$ on seedling emergence, plant establishment and growth}

Emergence of $A$. lappacea seeds was greatly promoted by $\mathrm{X} 3$ on both mine waste materials (Figures 4 and $5)$. With $X 3$, seedling emergence percentage was significantly increased from $0 \%$ on both unamended substrates to $62 \%$ on waste rock (Figure $4(A)$ ) and $54 \%$ on tailings (Figure $5(A)$ ). All pots had reached maximum emergence after 13 days.

Twenty days after sowing, no emergent seedling had survived on any of the unamended spoils (Figures 4 and 5). In contrast, early establishment of $A$. lappacea on all other treatments was successful (Figures 4(B) and $5(B))$. Survival reached a plateau after day 34, with no further significant plant death in both X3amended mine substrates (Figures $4(B)$ and $5(B)$ ). In $X 3$-amended waste rock, plant establishment percentage $(45 \%$, Figure $4(B))$ was not significantly different from the amended sand control $(41 \%$, Figure 4(B)). Although X3-amended tailings had lower establishment percentages (35\%, Figure 5(B)) than the amended sand control $(61 \%$, Figure $5(B))$, plants had established at a satisfactory percentage when compared to unamended tailings treatments $(0 \%$, Figure $5(\mathrm{~B}))$. 
Maximum shoot height of $A$. lappacea on waste rock amended with $X 3$ significantly increased $(p<0.05)$ to up to $28.3 \mathrm{~cm}$ after 55 days (Figure $4(C)$ ) but remained relatively lower $(p<0.05)$ compared to the two sand controls (above $44 \mathrm{~cm}$, Figure $4(C)$ ). On tailings amended with $X 3$, maximum shoot height was also significantly $(p<0.05)$ lower than controls (Figure $5(C))$. However, in both amended mine substrates, successfully established plants were vigorous and healthy and did not display any visible signs of toxicity on leaves throughout the experiment (Figures 4(D) and 5(D)).
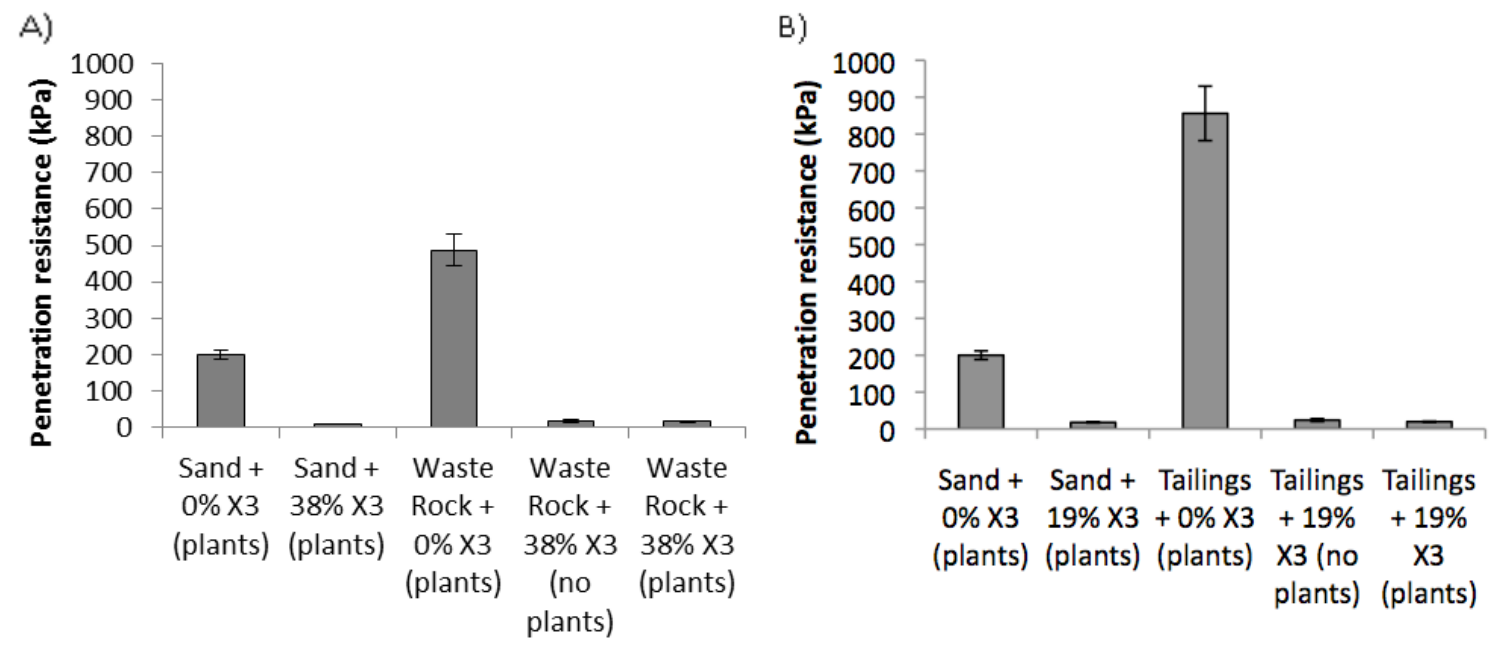

Figure 3 Penetration resistance of X3-amended substrates and corresponding controls 27 days after sowing for waste rock treatments and corresponding controls $(A)$, and tailings treatments and corresponding controls (B). Data are represented as the mean \pm standard error $(\mathrm{SE})(\mathrm{n}=3)$
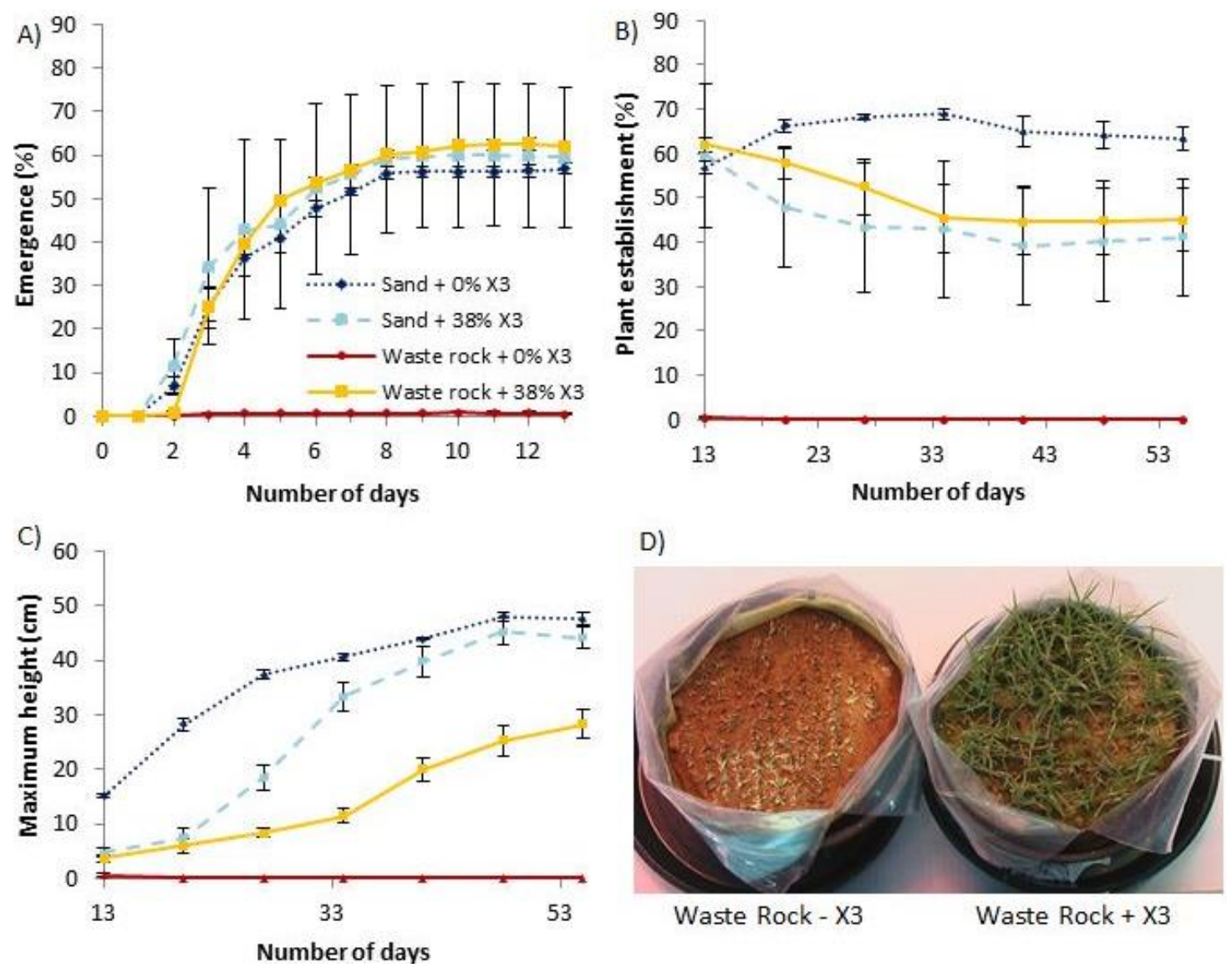

Figure 4 Development of Astrebla lappacea in pots with waste rock and corresponding controls. Seedling emergence (A), plant establishment (B), maximum plant height (C), and photograph showing waste rock pots unamended (left) and 
amended with $\mathrm{X} 3$ particles (right) 20 days after sowing (D). Vertical bars when larger than the symbol indicate \pm SE of the mean for $n=3$ 
Table 3 Concentration of key contaminants in soil solution $\left(\mathrm{mg} \mathrm{L}^{-1}\right)$ from each layer of waste rock and control sand treatments before sowing (Day 0 ) and 61 days after sowing. Data are represented as the mean \pm standard error (SE) $(\mathbf{n}=3)$

\begin{tabular}{|c|c|c|c|c|c|c|c|c|c|c|c|c|c|}
\hline \multirow[b]{3}{*}{ Element } & \multirow{3}{*}{$\begin{array}{c}\text { Time } \\
\text { Treatment } \\
\text { Pot Layer }\end{array}$} & \multicolumn{6}{|c|}{ Day 0} & \multicolumn{6}{|c|}{ Day 61} \\
\hline & & \multicolumn{2}{|c|}{ 0\% X3 (Plants) } & \multicolumn{2}{|c|}{$38 \%$ X3 (No Plants) } & \multicolumn{2}{|c|}{ 38\% X3 (Plants) } & \multicolumn{2}{|c|}{ 0\% X3 (Plants) } & \multicolumn{2}{|c|}{$38 \%$ X3 (No Plants) } & \multicolumn{2}{|c|}{ 38\% X3 (plants) } \\
\hline & & Top & Bottom & Top & Bottom & Top & Bottom & Top & Bottom & Top & Bottom & Top & Bottom \\
\hline \multirow{3}{*}{$\begin{array}{c}\text { Al } \\
\left(\mathrm{mg} \mathrm{L}^{-1}\right)\end{array}$} & Waste & $1,415.1$ & $1,646.5$ & 14.81 & $1,455.5$ & 18.9 & $1,175.03$ & $1,107.86$ & $1,384.91$ & 69.02 & 563.52 & 8.88 & 48.79 \\
\hline & rock & \pm 56.73 & \pm 152.78 & \pm 3.05 & \pm 61.54 & \pm 4.79 & \pm 22.28 & \pm 207.82 & \pm 162.87 & \pm 40.67 & \pm 252.15 & \pm 3.53 & \pm 4.47 \\
\hline & Sand & $\begin{array}{c}0.19 \\
\pm 0.02\end{array}$ & $\begin{array}{c}0.16 \\
\pm 0.03\end{array}$ & - & - & $\begin{array}{c}1.16 \\
\pm 0.19\end{array}$ & $\begin{array}{c}0.15 \\
\pm 0.01\end{array}$ & $\begin{array}{c}0.1 \\
\pm 0.08\end{array}$ & $\begin{array}{c}0.14 \\
\pm 0.05\end{array}$ & - & - & $\begin{array}{c}0.55 \\
\pm 0.24\end{array}$ & $\begin{array}{c}0.06 \\
\pm 0.02\end{array}$ \\
\hline \multirow[t]{2}{*}{$\begin{array}{c}\mathrm{Cu} \\
\left(\mathrm{mg} \mathrm{L}^{-1}\right)\end{array}$} & $\begin{array}{c}\text { Waste } \\
\text { Rock }\end{array}$ & $\begin{array}{l}151.96 \\
\pm 8.83\end{array}$ & $\begin{array}{r}175.99 \\
\pm 15.72\end{array}$ & $\begin{array}{c}1.59 \\
\pm 0.25\end{array}$ & $\begin{array}{l}155.93 \\
\pm 6.42\end{array}$ & $\begin{array}{r}1.99 \\
\pm 0.43\end{array}$ & $\begin{array}{l}132.06 \\
\pm 2.57\end{array}$ & $\begin{array}{c}97.53 \\
\pm 15.43\end{array}$ & $\begin{array}{r}133.35 \\
\pm 12.43\end{array}$ & $\begin{array}{c}7.68 \\
\pm 3.77\end{array}$ & $\begin{array}{r}53.02 \\
\pm 21.3\end{array}$ & $\begin{array}{c}1.69 \\
\pm 0.59\end{array}$ & $\begin{array}{c}7.43 \\
\pm 0.67\end{array}$ \\
\hline & Sand & $\begin{array}{c}0.02 \\
\pm 0.00\end{array}$ & $\begin{array}{c}0.01 \\
\pm 0.00\end{array}$ & - & - & $\begin{array}{c}0.06 \\
\pm 0.02\end{array}$ & $\begin{array}{c}0.01 \\
\pm 0.00\end{array}$ & $\begin{array}{c}0.01 \\
\pm 0.00\end{array}$ & $\begin{array}{c}0.01 \\
\pm 0.00\end{array}$ & - & - & $\begin{array}{c}0.16 \pm \\
0.08\end{array}$ & $\begin{array}{c}0.02 \\
\pm 0.00\end{array}$ \\
\hline \multirow[t]{2}{*}{$\begin{array}{c}\mathrm{Zn} \\
\left(\mathrm{mg} \mathrm{L}^{-1}\right)\end{array}$} & $\begin{array}{c}\text { Waste } \\
\text { Rock }\end{array}$ & $\begin{array}{r}23.71 \\
\pm 0.95\end{array}$ & $\begin{array}{r}27.51 \\
\pm 2.32\end{array}$ & $\begin{array}{c}1.21 \\
\pm 0.17\end{array}$ & $\begin{array}{c}24.01 \\
\pm 1\end{array}$ & $\begin{array}{c}1.30 \\
\pm 0.26\end{array}$ & $\begin{array}{r}19.71 \\
\pm 0.30\end{array}$ & $\begin{array}{r}17.42 \\
\pm 2.49\end{array}$ & $\begin{array}{r}19.82 \\
\pm 1.77\end{array}$ & $\begin{array}{c}1.50 \\
\pm 0.77\end{array}$ & $\begin{array}{c}8.39 \\
\pm 3.56\end{array}$ & $\begin{array}{c}0.31 \pm \\
0.08\end{array}$ & $\begin{array}{c}0.91 \\
\pm 0.07\end{array}$ \\
\hline & Sand & $\begin{array}{c}0.02 \\
\pm 0.00\end{array}$ & $\begin{array}{c}0.02 \\
\pm 0.00\end{array}$ & - & - & $\begin{array}{c}0.04 \\
\pm 0.01\end{array}$ & $\begin{array}{c}0.01 \\
\pm 0.00\end{array}$ & $\begin{array}{c}0.02 \\
\pm 0.00\end{array}$ & $\begin{array}{c}0.03 \\
\pm 0.00\end{array}$ & - & - & $\begin{array}{c}0.13 \pm \\
0.02\end{array}$ & $\begin{array}{c}0.08 \\
\pm 0.03\end{array}$ \\
\hline \multirow[t]{2}{*}{$\begin{array}{c}M n \\
\left(\mathrm{mg} \mathrm{L}^{-1}\right)\end{array}$} & $\begin{array}{c}\text { Waste } \\
\text { Rock }\end{array}$ & $\begin{array}{c}42.7 \\
\pm 1.44\end{array}$ & $\begin{array}{r}49.42 \\
\pm 3.63\end{array}$ & $\begin{array}{c}3.68 \\
\pm 0.31\end{array}$ & $\begin{array}{r}43.63 \\
\pm 0.92\end{array}$ & $\begin{array}{c}3.72 \\
\pm 0.55\end{array}$ & $\begin{array}{r}35.83 \\
\pm 0.91\end{array}$ & $\begin{array}{r}241.81 \\
\pm 15.67\end{array}$ & $\begin{array}{r}84.53 \\
\pm 3.31\end{array}$ & $\begin{array}{l}12.37 \\
\pm 4.12\end{array}$ & $\begin{array}{l}21.67 \\
\pm 7.39\end{array}$ & $\begin{array}{c}16.28 \pm \\
2.11\end{array}$ & $\begin{array}{c}7.47 \\
\pm 0.42\end{array}$ \\
\hline & Sand & $\begin{array}{c}0.04 \\
\pm 0.00\end{array}$ & $\begin{array}{c}0.03 \\
\pm 0.00\end{array}$ & - & - & $\begin{array}{c}0.04 \\
\pm 0.01\end{array}$ & $\begin{array}{c}0.03 \\
\pm 0.01\end{array}$ & $\begin{array}{c}0.69 \\
\pm 0.38\end{array}$ & $\begin{array}{c}0.01 \\
\pm 0.00\end{array}$ & - & - & $\begin{array}{c}1.93 \\
\pm 0.69\end{array}$ & $\begin{array}{c}0.09 \\
\pm 0.05\end{array}$ \\
\hline \multirow[t]{2}{*}{$\begin{array}{c}\text { Co } \\
\left(\mathrm{mg} \mathrm{L}^{-1}\right)\end{array}$} & $\begin{array}{c}\text { Waste } \\
\text { Rock }\end{array}$ & $\begin{array}{c}1.52 \\
\pm 0.05\end{array}$ & $\begin{array}{c}1.73 \\
\pm 0.12\end{array}$ & $\begin{array}{c}0.16 \\
\pm 0.01\end{array}$ & $\begin{array}{c}1.55 \\
\pm 0.07\end{array}$ & $\begin{array}{c}0.15 \\
\pm 0.03\end{array}$ & $\begin{array}{c}1.29 \\
\pm 0.03\end{array}$ & $\begin{array}{c}1.27 \\
\pm 0.17\end{array}$ & $\begin{array}{c}1.37 \\
\pm 0.12\end{array}$ & $\begin{array}{c}0.12 \\
\pm 0.06\end{array}$ & $\begin{array}{c}0.6 \\
\pm 0.26\end{array}$ & $\begin{array}{c}0.04 \\
\pm 0.01\end{array}$ & $\begin{array}{c}0.06 \\
\pm 0.01\end{array}$ \\
\hline & Sand & $\begin{array}{c}0.03 \\
\pm 0.00\end{array}$ & $\begin{array}{c}0.02 \\
\pm 0.00\end{array}$ & - & - & $\begin{array}{c}0.03 \\
\pm 0.00\end{array}$ & $\begin{array}{c}0.05 \\
\pm 0.01\end{array}$ & $\begin{array}{c}0.03 \\
\pm 0.00\end{array}$ & $\begin{array}{c}0.01 \\
\pm 0.00\end{array}$ & - & - & $\begin{array}{c}0.26 \\
\pm 0.09\end{array}$ & $\begin{array}{c}0.04 \\
\pm 0.01\end{array}$ \\
\hline
\end{tabular}


Table 4 Concentration of key contaminants in soil solution $\left(\mathrm{mg} \mathrm{L}^{-1}\right)$ from each layer of tailings and control sand treatments before sowing (Day 0 ) and 61 days after sowing. Data are represented as the mean \pm standard error $(S E)(n=3)$

\begin{tabular}{|c|c|c|c|c|c|c|c|c|c|c|c|c|c|}
\hline \multirow[b]{3}{*}{ Element } & \multirow{3}{*}{$\begin{array}{c}\text { Time } \\
\text { Treatment } \\
\text { Pot Layer }\end{array}$} & \multicolumn{6}{|c|}{ Day 0} & \multicolumn{6}{|c|}{ Day 61} \\
\hline & & \multicolumn{2}{|c|}{ 0\% X3 (Plants) } & \multicolumn{2}{|c|}{$19 \%$ X3 (No Plants) } & \multicolumn{2}{|c|}{ 19\% X3 (Plants) } & \multicolumn{2}{|c|}{ 0\% X3 (Plants) } & \multicolumn{2}{|c|}{$19 \%$ X3 (No Plants) } & \multicolumn{2}{|c|}{$19 \%$ X3 (Plants) } \\
\hline & & Top & Bottom & Top & Bottom & Top & Bottom & Top & Bottom & Top & Bottom & Top & Bottom \\
\hline \multirow[t]{2}{*}{$\begin{array}{c}\mathrm{Zn} \\
\left(\mathrm{mg} \mathrm{L}^{-1}\right)\end{array}$} & Tailings & $\begin{array}{r}67.77 \\
\pm 4.09\end{array}$ & $59.16 \pm 1.67$ & $\begin{array}{c}3.52 \\
\pm 0.31\end{array}$ & $\begin{array}{r}54.18 \\
\pm 0.64\end{array}$ & $\begin{array}{c}2.47 \\
\pm 0.29\end{array}$ & $\begin{array}{r}52.85 \\
\pm 1.27\end{array}$ & $\begin{array}{r}33.88 \\
\pm 2.48\end{array}$ & $\begin{array}{r}57.05 \\
\pm 5.11\end{array}$ & $\begin{array}{l}11.17 \\
\pm 1.07\end{array}$ & $\begin{array}{r}18.51 \\
\pm 2.25\end{array}$ & $\begin{array}{c}5.88 \\
\pm 0.36\end{array}$ & $\begin{array}{c}9.08 \\
\pm 0.62\end{array}$ \\
\hline & Sand & $\begin{array}{c}0.02 \\
\pm 0.00\end{array}$ & $\begin{array}{c}0.02 \\
\pm 0.00\end{array}$ & - & - & $\begin{array}{c}0.04 \\
\pm 0.01\end{array}$ & $\begin{array}{c}0.05 \\
\pm 0.01\end{array}$ & $\begin{array}{c}0.02 \\
\pm 0.00\end{array}$ & $\begin{array}{c}0.03 \\
\pm 0.00\end{array}$ & - & - & $\begin{array}{c}0.21 \\
\pm 0.04\end{array}$ & $\begin{array}{c}0.28 \\
\pm 0.15\end{array}$ \\
\hline \multirow[t]{2}{*}{$\begin{array}{c}\mathrm{Mn} \\
\left(\mathrm{mg} \mathrm{L}^{-1}\right)\end{array}$} & Tailings & $\begin{array}{r}90.99 \\
\pm 5.02\end{array}$ & $\begin{array}{r}79.42 \\
\pm 1.99\end{array}$ & $\begin{array}{c}6.93 \\
\pm 0.67\end{array}$ & $\begin{array}{r}71.68 \\
\pm 2.06\end{array}$ & $\begin{array}{c}4.82 \\
\pm 0.49\end{array}$ & $\begin{array}{r}70.56 \\
\pm 0.87\end{array}$ & $\begin{array}{c}501.03 \\
\pm 4.18\end{array}$ & $\begin{array}{c}200.09 \\
\pm 108.33\end{array}$ & $\begin{array}{r}55.11 \\
\pm 4.40\end{array}$ & $\begin{array}{l}118.95 \\
\pm 6.07\end{array}$ & $\begin{array}{r}24.56 \\
\pm 2.62\end{array}$ & $\begin{array}{r}63.49 \\
\pm 11.62\end{array}$ \\
\hline & Sand & $\begin{array}{c}0.04 \\
\pm 0.00\end{array}$ & $\begin{array}{c}0.03 \\
\pm 0.00\end{array}$ & - & - & $\begin{array}{c}0.07 \\
\pm 0.03\end{array}$ & $\begin{array}{c}0.08 \\
\pm 0.01\end{array}$ & $\begin{array}{c}0.69 \\
\pm 0.38\end{array}$ & $\begin{array}{c}0.01 \\
\pm 0.00\end{array}$ & - & - & $\begin{array}{c}4.01 \\
\pm 1.23\end{array}$ & $\begin{array}{c}1.79 \\
\pm 1.23\end{array}$ \\
\hline \multirow[t]{2}{*}{$\begin{array}{c}\text { Co } \\
\left(\mathrm{mg} \mathrm{L}^{-1}\right)\end{array}$} & Tailings & $\begin{array}{c}6.82 \\
\pm 0.36\end{array}$ & $\begin{array}{c}6.20 \\
\pm 0.14\end{array}$ & $\begin{array}{c}0.67 \\
\pm 0.02\end{array}$ & $\begin{array}{c}5.72 \\
\pm 0.08\end{array}$ & $\begin{array}{c}0.52 \\
\pm 0.04\end{array}$ & $\begin{array}{c}5.59 \\
\pm 0.07\end{array}$ & $\begin{array}{c}5.50 \\
\pm 0.30\end{array}$ & $\begin{array}{c}6.44 \\
\pm 0.31\end{array}$ & $\begin{array}{c}3.02 \\
\pm 0.25\end{array}$ & $\begin{array}{c}4.00 \\
\pm 0.34\end{array}$ & $\begin{array}{c}1.80 \\
\pm 0.07\end{array}$ & $\begin{array}{c}2.26 \\
\pm 0.12\end{array}$ \\
\hline & Sand & $\begin{array}{c}0.03 \\
\pm 0.00\end{array}$ & $\begin{array}{c}0.02 \\
\pm 0.00\end{array}$ & - & - & $\begin{array}{c}0.04 \\
\pm 0.00\end{array}$ & $\begin{array}{c}0.03 \\
\pm 0.00\end{array}$ & $\begin{array}{c}0.03 \\
\pm 0.00\end{array}$ & $\begin{array}{c}0.01 \\
\pm 0.00\end{array}$ & - & - & $\begin{array}{c}0.23 \\
\pm 0.01\end{array}$ & $\begin{array}{c}0.23 \\
\pm 0.11\end{array}$ \\
\hline \multirow[t]{2}{*}{$\begin{array}{c}C d \\
\left(\mathrm{mg} \mathrm{L}^{-1}\right)\end{array}$} & Tailings & $\begin{array}{c}1.71 \\
\pm 0.15\end{array}$ & $\begin{array}{c}1.45 \\
\pm 0.05\end{array}$ & $\begin{array}{c}0.21 \\
\pm 0.02\end{array}$ & $\begin{array}{c}1.38 \\
\pm 0.02\end{array}$ & $\begin{array}{c}0.18 \\
\pm 0.01\end{array}$ & $\begin{array}{c}1.29 \\
\pm 0.03\end{array}$ & $\begin{array}{c}0.73 \\
\pm 0.06\end{array}$ & $\begin{array}{c}0.62 \\
\pm 0.04\end{array}$ & $\begin{array}{c}0.10 \\
\pm 0.01\end{array}$ & $\begin{array}{c}0.16 \\
\pm 0.01\end{array}$ & $\begin{array}{c}0.05 \\
\pm 0.00\end{array}$ & $\begin{array}{c}0.11 \\
\pm 0.01\end{array}$ \\
\hline & Sand & $\begin{array}{c}0.03 \\
\pm 0.00\end{array}$ & $\begin{array}{c}0.05 \\
\pm 0.01\end{array}$ & - & - & $\begin{array}{c}0.04 \\
\pm 0.01\end{array}$ & $\begin{array}{c}0.02 \\
\pm 0.00\end{array}$ & $\begin{array}{c}0.01 \\
\pm 0.00\end{array}$ & $\begin{array}{c}0.01 \\
\pm 0.00\end{array}$ & - & - & $\begin{array}{c}0.01 \\
\pm 0.00\end{array}$ & $\begin{array}{c}0.01 \\
\pm 0.00\end{array}$ \\
\hline \multirow[t]{2}{*}{$\begin{array}{c}\mathrm{Na} \\
\left(\mathrm{mg} \mathrm{L}^{-1}\right)\end{array}$} & Tailings & $\begin{array}{l}2,829.82 \\
\pm 134.27\end{array}$ & $\begin{array}{c}2,330.15 \\
\pm 62.05\end{array}$ & $\begin{array}{r}392.55 \\
\pm 19.96\end{array}$ & $\begin{array}{c}2,099.82 \\
\pm 44.52\end{array}$ & $\begin{array}{r}307.42 \\
\pm 39.29\end{array}$ & $\begin{array}{c}2,083.48 \\
\pm 23.54\end{array}$ & $\begin{array}{c}2,024.19 \\
\pm 78.75\end{array}$ & $\begin{array}{l}1,690.52 \\
\pm 143.90\end{array}$ & $\begin{array}{r}753.96 \\
\pm 87.73\end{array}$ & $\begin{array}{r}911.32 \\
\pm 12.75\end{array}$ & $\begin{array}{r}415.29 \\
\pm 61.85\end{array}$ & $\begin{array}{r}510.42 \\
\pm 67.17\end{array}$ \\
\hline & Sand & $\begin{array}{c}9.43 \\
\pm 0.19\end{array}$ & $\begin{array}{r}11.99 \\
\pm 0.58\end{array}$ & - & - & $\begin{array}{c}2.06 \\
\pm 0.04\end{array}$ & $\begin{array}{l}10.25 \\
\pm 0.52\end{array}$ & $\begin{array}{c}0.35 \\
\pm 0.08\end{array}$ & $\begin{array}{c}3.21 \\
\pm 0.24\end{array}$ & - & - & $\begin{array}{r}14.51 \\
\pm 1.99\end{array}$ & $\begin{array}{r}13.38 \\
\pm 6.10\end{array}$ \\
\hline \multirow[t]{2}{*}{$\begin{array}{c}S \\
\left(m g L^{-1}\right)\end{array}$} & Tailings & $\begin{array}{l}41,177 \\
\pm 3,617\end{array}$ & $\begin{array}{r}32,615 \\
\pm 1,205\end{array}$ & $\begin{array}{l}5,841 \\
\pm 321\end{array}$ & $\begin{array}{c}30,638 \\
\pm 402\end{array}$ & $\begin{array}{l}4,708 \\
\pm 554\end{array}$ & $\begin{array}{c}30,000 \\
\pm 432\end{array}$ & $\begin{array}{c}26,863 \\
\pm 780\end{array}$ & $\begin{array}{r}20,416 \\
\pm 2,475\end{array}$ & $\begin{array}{l}5,916 \\
\pm 394\end{array}$ & $\begin{array}{r}10,815 \\
\pm 1,004\end{array}$ & $\begin{array}{l}3,484 \\
\pm 501\end{array}$ & $\begin{array}{l}5,125 \\
\pm 804\end{array}$ \\
\hline & Sand & $\begin{array}{c}8.26 \\
\pm 1.30\end{array}$ & $\begin{array}{c}7.25 \\
\pm 1.50\end{array}$ & - & - & $\begin{array}{r}13.44 \\
\pm 0.88\end{array}$ & $\begin{array}{c}9.20 \\
\pm 1.06\end{array}$ & $\begin{array}{c}0.35 \\
\pm 0.05\end{array}$ & $\begin{array}{c}0.35 \\
\pm 0.02\end{array}$ & - & - & $\begin{array}{c}5.57 \\
\pm 1.51\end{array}$ & $\begin{array}{c}3.05 \\
\pm 1.80\end{array}$ \\
\hline
\end{tabular}



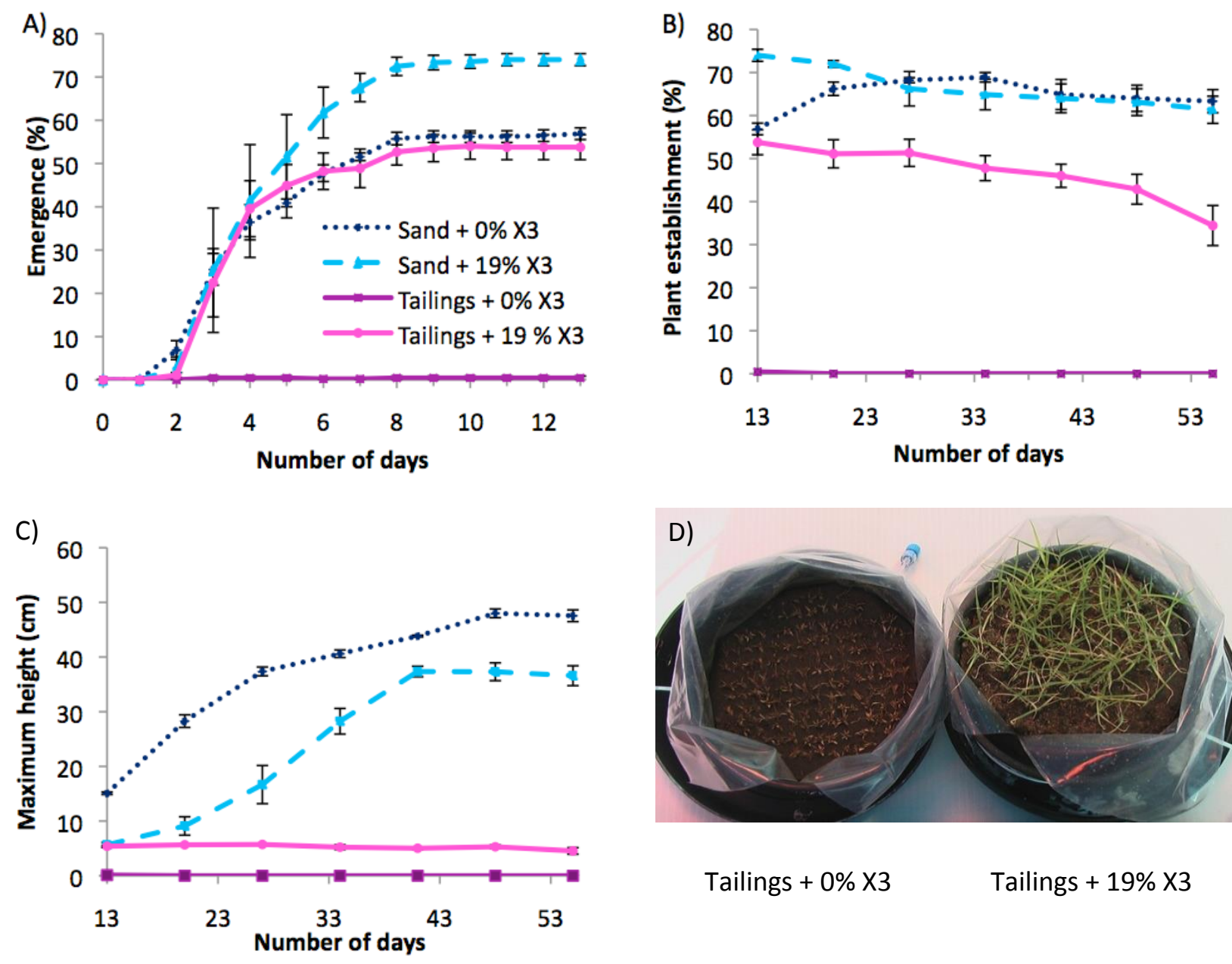

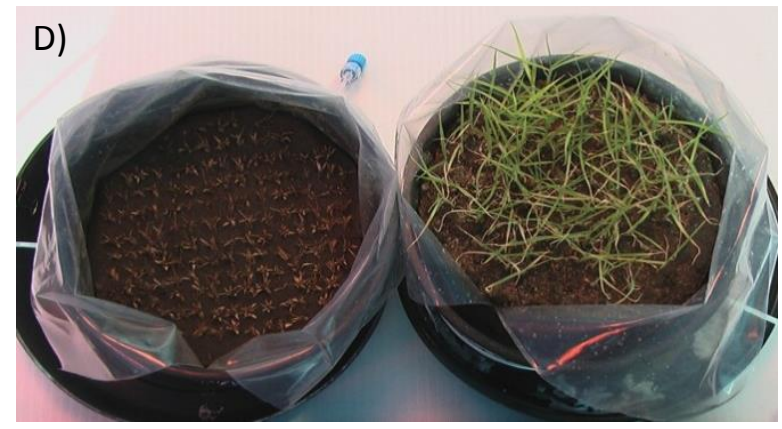

Tailings $+0 \% \times 3$
Tailings $+19 \%$ X3

Figure 5 Development of Astrebla lappacea in pots with tailings and corresponding controls. Seedling emergence (A), plant establishment (B), maximum plant height (C), and photograph showing tailings pots unamended (left) and amended with $X 3$ particles (right) 20 days after sowing (D). Vertical bars when larger than the symbol indicate \pm SE of the mean for $n=3$

\section{Discussion}

This study provides a more detailed understanding of the novel $X 3$ remediation technique in terms of interactions between the $\mathrm{X} 3$ particles and two contrasting toxic metalliferous mine waste materials: highly acidic, extremely saline and metal-polluted waste rock, and neutral extremely saline tailings with lower metal availability to plants. With the addition of $X 3$, substrate solution quality was immediately improved in both waste rock and tailings by the marked reductions in contaminant metal concentrations below their phytotoxicity thresholds in both waste rock ( $\mathrm{Al}, \mathrm{Cu}, \mathrm{Zn}, \mathrm{Mn}$ and $\mathrm{Co}$ ) and tailing ( $\mathrm{Zn}, \mathrm{Mn}, \mathrm{Co}$ and $\mathrm{Cd}$ ). Our study showed that $\mathrm{X} 3$ particles are very versatile and were capable of adapting to various types of contaminations in the differing substrates; i.e. X3 had high affinities for soluble $\mathrm{Al}, \mathrm{Cu}$ and $\mathrm{Zn}$ in waste rock (94.5 to $98.7 \%$ reduction in concentration), whereas soluble $\mathrm{Zn}$ was the metal most extensively sequestered in tailings (96.4\%). The increase in $\mathrm{pH}$ for $\mathrm{X} 3$-amended substrates (both waste rock and tailings) was an additional factor that may have slightly reduced metal solubility (Sauvé et al., 2000). Decreased metal concentrations in contaminated soils has been demonstrated using polyacrylate, another hydrogel polymer, particularly reductions of lead $(\mathrm{Pb})$ by up to $66 \%$ in $\mathrm{Pb}$-contaminated spoil (Guiwei et al., 2008) and reductions of $\mathrm{Cd}$, nickel ( $\mathrm{Ni}$ ) and $\mathrm{Zn}$ (together in a same substrate) by up to $47 \%$ (de Varennes et al., 2006). However, the polyacrylates used by Guiwei et al. (2008) and de Varennes et al. (2009) reduced soil urease activity, and the metal-binding and water-holding effects were competitive. In contrast, X3 was 
highly efficient at both reducing various metals present at phytotoxic plant available concentrations (by up to $98.7 \%$ ) and increasing plant available water levels for plants which confirms the potential of this technology for in situ remediation of mine spoils, particularly under arid and semi-arid environments.

Our study of $X 3$ particles showed that this synthetic polymer increases water-holding capacity in both waste rock and tailings, while its hydrogel structure does not impose substrate oxygen limitations. X3 water-holding capacity was not hampered by the extreme salinity of these substrates in solution as opposed to some other gel-forming synthetic polymers (Johnson, 1984). Our findings are consistent with Shi et al. (2010) who demonstrated that the hydrophilic properties of a polyacrylamide-based polymer (Stockosorb) excluded $\mathrm{Na}^{+}$and $\mathrm{Cl}^{-}$from the substrate while the high water holding capacity of the polymer effectively provided desalinated water to the plant. The osmotic potential of the waste rock and tailings on their own were sufficiently low $(<<-2 \mathrm{MPa})$ to hinder plant growth in these media without amendment. The addition of $\mathrm{X} 3$ particles raised osmotic potential in both substrates and thereby contributed to greater PAW by increasing both osmotic potential and water holding capacity, and could also contribute to lowering the effect of salt toxicity on plant growth. Plant water availability and osmotic potential were lower in X3amended tailings compared to X3-amended waste rock. Factors that may have influenced the difference between the substrates include (a) the greater (almost twice) $\mathrm{EC}_{1: 5 \text { water }}$ of the tailings compared to the waste rock, (b) the nature of the salts in each substrate, as different salts were shown to impact polyacrylamide hydrogels differently (Johnson, 1984), and (c) substrate particle size, where the tailings were finer-grained than waste rock and thus would retain a greater volume of solution and therefore a greater mass of dissolved salts at $-1.5 \mathrm{MPa} \Psi_{\mathrm{m}}$. X3 considerably reduced salinity of the substrates, especially for tailings, where EC of unamended substrate solution was higher than the EC for seawater $\left(>51 \mathrm{dS} \mathrm{m}^{-1}\right.$ ) (Suttar, 1990). The concentrations of non-metallic substrate contaminants in solution, particularly $\mathrm{S}$ and $\mathrm{Na}$ in tailings, were reaching highly toxic concentrations (Mulvey and Elliot, 2000) and our study showed that X3 was also capable of greatly reducing their concentrations in solution, by up to $89 \%$. X3 particles increased the osmotic potential and as a consequence improved PAW while providing oxygenated conditions in both the waste rock and tailings, both of which were extremely saline media. Increase in the osmotic potential indicates a reduction in the salt concentration and a more desirable plant growth environment. Our findings are consistent with other studies on the capacity of superabsorbent polymers to reduce salinity and improve plant survival (water-use efficiency) under osmotic stress (Sayed et al., 1991; Hüttermann et al., 2009; Dorraji et al., 2010).

Values of penetration resistance measured in the surface of the unamended waste rock and tailings were found to affect root penetration of perennial grass species (Campbell and Swain, 1973), particularly in acidic conditions (Haling et al., 2011). The high values for the unamended mine substrates were obtained despite the high water content (close to field capacity) during measurement, suggesting that further drying of the substrate surface would increase its strength to levels that would prevent seedling emergence and root growth. The addition of the X3 hydrogel significantly modified the physical characteristics of both mine materials and reduced substrate penetration resistance providing a suitable environment for emergence, root penetration and exploration and plant establishment (Guiwei et al., 2008; Haling et al., 2011).

Our study demonstrated that the X3 remediation technique successfully alleviated phytotoxicity in highly contaminated mine waste rock and tailings where plant establishment had previously failed. As a result, $X 3$ promoted successful emergence and early establishment of the native metallophyte species $A$. lappacea on both mine wastes. In contrast with other nanoparticles such as $\mathrm{Fe}_{3} \mathrm{O}_{4}$ or $\mathrm{TiO}_{2}$ 'nanopowders' or other gelforming polyacrylamide soil conditioners which were found to, respectively, reduce germination potential of cucumber seeds (Mushtaq, 2011), or inhibit germination of lettuce (Woodhouse and Johnson, 1991), our X3 particles were not toxic to seed germination, emergence or plant establishment. The capacity of X3 to mitigate the effects of different types of contamination such as metals, salinity, acidity and substrate penetration resistance confirms the technology as an asset for mine waste remediation. Another polyacrylate polymer was previously shown to reduce metal concentrations in contaminated substrates and to allow the establishment of perennial ryegrass (de Varennes and Torres, 1999; de Varennes et al., 2006, 2009), but this polymer effectively reduced soluble $\mathrm{Cu}$ in substrate in the presence of plants 
(ryegrass) only (de Varennes and Torres, 1999). In contrast, X3 polymer significantly reduced Cu and other metal contamination whether it was applied with plants or without. The combination of $X 3$ and the metallophyte grass $A$. lappacea was, however, shown to be more beneficial to substrate quality than X3 alone in terms of $\mathrm{pH}, \mathrm{EC}$, and metal and other contaminant concentrations in substrate solution. The X3 remediation technology shows great promise as an effective amendment in tandem with phytoremediation to maximise the rehabilitation potential of a site in a sustainable manner. The cost of the X 3 technology will depend on the level of contamination at sites and method of application employed, but should be in the range of other polyacrylamide-based soil conditioners which recently became widely applied for degraded land management because they were shown to be sustainable, environmentally friendly and highly efficient and inexpensive (Orts et al., 1999; Sojka et al., 2007; Guiwei et al., 2008; Hüttermann et al., 2009), with cost estimated at US\$ 2-4 $\mathrm{kg}^{-1}$ (Hüttermann et al., 2009), or $€ 2 \mathrm{~kg}^{-1}$ (Guiwei et al., 2008).

\section{Conclusion}

This study showed that $\mathrm{X} 3$ particle amendment of surface mine substrates alleviated metal and salinity toxicity, improved substrate penetration resistance, acidity and plant water relations and allowed germination and healthy establishment of the native metallophyte grass $A$. lappacea in the polluted mine waste rock and tailings tested. This novel remediation technique promises to be very robust, cost-effective and applicable to a wide range of situations where decades of attempted plant establishment had previously been unsuccessful. Further study is required to test the sustainability of the X3 technology via a long-term glasshouse experiment to determine whether the plant establishment enabled by $X 3$ can be sustained. Future research will also examine the potential toxicity of X3 particles to soil biota, and the X3 technique (including its potential longevity, methods of particle deployment and the effects of different seasonal conditions on particle properties and plant growth as well as interaction of the particles with soil microbes) will be tested and validated in a pilot field trial at a mine site under extreme environmental conditions.

\section{Acknowledgements}

This study was supported by Xstrata Technology, Commercialisation Australia and the Department of Employment, Economic Development and Innovation (DEEDI Mines). The assistance of mine site personnel and comments of the anonymous reviewers are gratefully acknowledged.

\section{References}

ASEC (2001) Australian State of the Environment Committee, Australia State of the Environment 2001, Collingwood, Victoria, p. 71.

Baker, A.J.M. (1981) Accumulators and excluders - strategies in the response of plants to heavy metals, Journal of Plant Nutrition, Vol. 3, pp. 643-654.

Baker, A.J.M. (1987) Metal tolerance, New Phytologist, Vol. 106 (Suppl.), pp. 93-111.

Bohn, H.L. (1971) Redox potentials, Soil Science, Vol. 112, pp. 39-45.

Brady, N.C. and Weil, R.R. (2004) Elements of the nature and properties of soils, Pearson Education.

Campbell, M.H. and Swain, F.G. (1973) Effect of strength, tilth and heterogeneity of the soil surface on radicle-entry of surfacesown seeds, Grass and Forage Science, Vol. 28, pp. 41-50.

CSIRO (2004) CSIRO Sustainability Network, Network Letter 46E, Australia, 24 p., viewed 7 March 2011, http://www.bml.csiro.au/susnetnl/netwl46E.pdf.

Cunningham, S. and Berti, W. (1993) Remediation of contaminated soils with green plants: an overview, In Vitro Cellular \& Developmental Biology - Plant, Vol. 29, pp. 207-212.

de Varennes, A., Cunha-Queda, C. and Ramos, A.R. (2009) Polyacrylate polymers as immobilizing agents to aid phytostabilization of two mine soils, Soil Use and Management, Vol. 25, pp. 133-140.

de Varennes, A., Goss, M.J. and Mourato, M. (2006) Remediation of a sandy soil contaminated with cadmium, nickel, and zinc using an insoluble polyacrylate polymer, Communications in Soil Science and Plant Analysis, Vol. 37, pp. 1,639-1,649.

de Varennes, A. and Torres, M.O. (1999) Remediation of a long-term copper-contaminated soil using a polyacrylate polymer, Soil Use and Management, Vol. 15, pp. 230-232.

Delaune, R.D., Pezeshki, S.R. and Pardue, J.H. (1990) An oxidation-reduction buffer for evaluating the physiological response of plants to root oxygen stress, Environmental and Experimental Botany, Vol. 30, pp. 243-247.

Dorraji, S.S., Golchin, A. and Ahmadi, S. (2010) The Effects of hydrophilic polymer and soil salinity on corn growth in sandy and loamy soils, CLEAN - Soil, Air, Water, Vol. 38, pp. 584-591. 
Garau, G., Castaldi, P., Santona, L., Deiana, P. and Melis, P. (2007) Influence of red mud, zeolite and lime on heavy metal immobilization, culturable heterotrophic microbial populations and enzyme activities in a contaminated soil, Geoderma, Vol. 142, pp. 47-57.

Guiwei, Q., De Varennes, A. and Cunha-Queda, C. (2008) Remediation of a mine soil with insoluble polyacrylate polymers enhances soil quality and plant growth, Soil Use and Management, Vol. 24, pp. 350-356.

Guterres, J., Rossato, L., Pudmenzky, A., Doley, D., Whittaker, M. and Schmidt, S. (2012) Micron-size metal-binding hydrogel particles improve germination and radicle elongation of Australian metallophyte grasses in mine waste rock and tailings, (2012) in Proceedings Seventh International Conference on Mine Closure (Mine Closure 2012), A.B. Fourie and M. Tibbett (eds), 25-27 September 2012, Brisbane, Australia, Australian Centre for Geomechanics, Perth, pp. 517-532.

Haling, R.E., Simpson, R.J., Culvenor, R.A., Lambers, H. and Richardson, A.E. (2011) Effect of soil acidity, soil strength and macropores on root growth and morphology of perennial grass species differing in acid-soil resistance, Plant Cell and Environment, Vol. 34, pp. 444-456.

Hüttermann, A., Orikiriza, L.J.B. and Agaba, H. (2009) Application of superabsorbent polymers for improving the ecological chemistry of degraded or polluted lands. CLEAN - Soil, Air, Water, Vol. 37, pp. 517-526.

Johnson, M.S. (1984) Effect of soluble salts on water absorption by gel-forming soil conditioners. Journal of the Science of Food and Agriculture, Vol. 35, pp. 1,063-1,066.

Khan, M.J. and Jones, D.L. (2009) Effect of composts, lime and diammonium phosphate on the phytoavailability of heavy metals in a copper mine tailing soil, Pedosphere, Vol. 19, pp. 631-641.

Klute, A. (1986) Water retention: laboratory methods, Methods of soils analysis, Part 1, 2nd edition, A. Klute, Agronomy monographs, Vol. 9, ASA and SSSA Madison, Wisconsin, pp. 597-618.

Kramer, P.J. and Boyer, J.S. (1995) Water relations of plants and soils, Academic Press, San Diego/Sydney.

Lasat, M.M. (2000) Phytoextraction of metals from contaminated soil: a review of plant/soil/metal interaction and assessment of pertinent agronomic issues, Journal of Hazardous Substance Research, Vol. 2, pp. 1-25.

Letey, J., Clark, P. and Amrhein, C. (1992) A greenhouse experiment finds water-sorbing polymers do not conserve water, California Agriculture, Vol. 46, pp. 9-10.

Levy, G.J., Ben-Hur, M. and Agassi, M. (1991) The effect of polyacrylamide on runoff, erosion, and cotton yield from fields irrigated with moving sprinkler systems, Irrigation Science, Vol. 12, pp. 55-60.

Loring, D.H. and Rantala, R.T.T. (1992) Manual for the geochemical analyses of marine sediments and suspended particulate matter, Earth-Science Reviews, Vol. 32, pp. 235-283.

Lottermoser, B.G. (2010) Introduction to mine wastes, Mine wastes, Springer Berlin Heidelberg, pp. 1-41.

LPSDP (2006) Mine rehabilitation: Leading Practice Sustainable Development Program for the Mining Industry, Department of Industry, Tourism and Resources, Canberra, ACT, Australia.

Mendez, M.O. and Maier, R.M. (2008a) Phytostabilization of mine tailings in arid and semiarid environments - an emerging remediation technology, Environmental Health Perspectives, Vol. 116, pp. 278-283.

Mendez, M.O. and Maier, R.M. (2008b) Phytoremediation of mine tailings in temperate and arid environments, Reviews in Environmental Science and Biotechnology, Vol. 7, pp. 47-59.

Menzies, N.W., Donn, M.J. and Kopittke, P.M. (2007) Evaluation of extractants for estimation of the phytoavailable trace metals in soils, Environmental Pollution, Vol. 145, pp. 121-130.

Mulligan, C.N., Yong, R.N. and Gibbs, B.F. (2001) Remediation technologies for metal-contaminated soils and groundwater: an evaluation, Engineering Geology, Vol. 60, pp. 193-207.

Mulvey, P.J. and Elliott, G.L. (2000) Toxicities in soils, Soils: their properties and management, 2nd Edition, P.E.V. Charman and B.W. Murphy (eds), Oxford University Press, South Melbourne, Australia.

Mushtaq, Y.K. (2011) Effect of nanoscale $\mathrm{Fe}_{3} \mathrm{O}_{4}, \mathrm{TiO}_{2}$ and carbon particles on cucumber seed germination, Journal of Environmental Science and Health, Part A, Vol. 46, pp. 1,732-1,735.

Orts, W.J., Sojka, R.E., Glenn, G.M. and Gross, R.A. (1999) Preventing soil erosion with polymer additives. Polymer News, 24, pp. 406-413.

Pimentel, D. (2006) Soil erosion: a food and environmental threat, Environment, Development and Sustainability, Vol. 8, pp. 119137.

Pudmenzky, A., Rossato, L., Doley, D., Ramirez, C. and Baker, A.J.M. (2009) Development of a metallophyte spatial database covering Australia, Mine Closure 2009: Fourth International Seminar on Mine Closure, A. Fourie and M. Tibbett (eds), Australian Centre for Geomechanics, Perth, WA, Australia.

Rayment, G.E. and Higginson, F.R. (1992) Australian laboratory handbook of soil and water chemical methods, Inkata Press, Melbourne/Sydney.

Rensing, C. and Maier, R.M. (2003) Issues underlying use of biosensors to measure metal bioavailability, Ecotoxicology and Environmental Safety, Vol. 56, pp. 140-147.

Rossato, L., MacFarlane, J., Whittaker, M., Pudmenzky, A., Doley, D., Schmidt, S. and Monteiro, M.J. (2011) Metal-binding particles alleviate lead and zinc toxicity during seed germination of metallophyte grass Astrebla lappacea, Journal of Hazardous Materials, Vol. 190, pp. 772-779.

Salt, D.E., Blaylock, M., Kumar, N.P.B.A., Dushenkov, V., Ensley, B.D., Chet, I. and Raskin, I. (1995) Phytoremediation: a novel strategy for the removal of toxic metals from the environment using plants, Biotechnology, Vol. 13, pp. 468-474.

Sauvé, S., Hendershot, W. and Allen, H.E. (2000) Solid-solution partitioning of metals in contaminated soils: Dependence on pH, total metal burden, and organic matter, Environmental Science \& Technology, Vol. 34, pp. 1,125-1,131. 
Sayed, H.E., Kirkwood, R.C. and Graham, N.B. (1991) The effects of a hydrogel polymer on the growth of certain horticultural crops under saline conditions, Journal of Experimental Botany, Vol. 42, pp. 891-899.

Shi, Y., Li, J., Shao, J., Deng, S.R., Wang, R.G., Li, N.Y., Sun, J., Zhang, H., Zhu, H.J., Zhang, Y.X., Zheng, X.J., Zhou, D.Z., Huttermann, A. and Chen, S.L. (2010) Effects of Stockosorb and Luquasorb polymers on salt and drought tolerance of Populus popularis, Scientia Horticulturae, Vol. 124, pp. 268-273.

Sinha, R., Herat, S. and Tandon, P.K. (2007) Phytoremediation: role of plants in contaminated site management, Environmental Bioremediation Technologies, S. Singh and R. Tripathi (eds), Springer Berlin Heidelberg, pp. 315-330.

Sojka, R.E., Bjorneberg, D.L., Entry, J.A., Lentz, R.D. and Orts, W.J. (2007) Polyacrylamide in agriculture and environmental land management, Advances in Agronomy, L.S. Donald (ed), Academic Press, pp. 75-162.

Suttar, S. (1990) Ribbons of blue handbook, Scitech, Victoria, Australia.

Taylor, H.M. and Brar, G.S. (1991) Effect of soil compaction on root development, Soil and Tillage Research, Vol. 19, pp. 111-119.

The State of Queensland (2011) Salinity management handbook, second edition, Department of Environment and Resource Management, Brisbane, Australia.

Whiting, S.N., Reeves, R.D., Richards, D., Johnson, M.S., Cooke, J.A., Malaisse, F., Paton, A., Smith, J.A.C., Angle, J.S., Chaney, R.L., Ginocchio, R., Jaffre, T., Johns, R., McIntyre, T., Purvis, O.W., Salt, D.E., Schat, H., Zhao, F.J. and Baker, A.J.M. (2004) Research priorities for conservation of metallophyte biodiversity and their potential for restoration and site remediation, Restoration Ecology, Vol. 12, pp. 106-116.

Wong, M.H. (2003) Ecological restoration of mine degraded soils, with emphasis on metal contaminated soils, Chemosphere, Vol. 50, pp. 775-780.

Woodhouse, J.M. and Johnson, M.S. (1991) The effect of gel-forming polymers on seed germination and establishment, Journal of Arid environments, Vol. 20, pp. 375-380. 
Ecosystem reconstruction 